The Journal of Animal \& Plant Sciences, 30(3): 2020, Page: 545-551

ISSN (print): 1018-7081; ISSN (online): 2309-8694

\title{
DETERMINATION OF SERO-PREVALENCE AND ASSOCIATED RISK FACTORS OF BOVINE VIRAL DIARRHEA VIRUS (BVDV) IN BOVINE POPULATION FROM SOUTHERN PUNJAB, PAKISTAN
}

\author{
A. Raheem ${ }^{1}$, A. Ahmad ${ }^{1 *}$, M. Rabbani ${ }^{2}$, A. Ghafoor ${ }^{1}$, A.A. Ajnum², M. Avais ${ }^{3}$, Qurat-ul-Ain ${ }^{1}$, R. M. Ramiz ${ }^{1}$ and \\ H. Ur-Rehman ${ }^{1}$ \\ ${ }^{1}$ University Diagnostic Lab, University of Veterinary \& Animal Sciences, Lahore, Pakistan \\ ${ }^{2}$ Department of Microbiology, University of Veterinary \& Animal Sciences, Lahore, Pakistan \\ ${ }^{3}$ Department of Clinical Medicine and Surgery, University of Veterinary \& Animal Sciences, Lahore, Pakistan \\ ${ }^{*}$ Corresponding author's email: iffivet@uvas.edu.pk \\ The paper was presented in International Buffalo Congress 2019, February 18-20, Lahore, Pakistan
}

\begin{abstract}
Bovine viral diarrhea (BVD) is an infectious disease of cattle and buffaloes, caused by bovine viral diarrhea virus (BVDV) and is distributed worldwide. BVDV leads to considerable economic losses and causes productive and reproductive problems. In this study, sero-prevalence and risk factors associated with BVDV in dairy animals of southern Punjab, Pakistan were determined. Three main Divisions of Southern Punjab including Bahawalpur, Multan and Dera Ghazi khan having a high density of animals, were selected for sampling. The farms having some reproductive problems were targeted for the collection of samples. Sample size was calculated by using Thrushfield formula assuming $50 \%$ prevalence of BVDV. In this study, a total of 719 samples from cattle $(n=651)$ and buffaloes $(n=68)$ were taken from 40 different dairy herds and processed for the presence of antibodies against BVDV through antibody capture ELISA. Out of all processed samples, overall, $18.77 \%$ positivity against BVDV was observed. Out of cattle samples $(\mathrm{n}=651), 19.81 \%(129 / 651)$ animals showed seroconversion against BVDV and 8.82\% (6/68) in buffaloes, respectively. In this study, various risk factors associated with BVD such as entry of new animals, biosecurity, herd size and abortion were evaluated using odds ratio. It was interesting to note that only the entry of newly purchased animals showed a positive association with BVDV. The study concluded that BVDV is circulating in dairy animals of southern Punjab, Pakistan, and there is a need to test the status of newly purchased animals for BVDV before their entry in the farms.
\end{abstract}

Keywords: Bovine viral diarrhea virus, BVDV, Sero-prevalence, Risk factors, Southern Punjab.

https://doi.org/10.36899/JAPS.2020.3.0064

Published online March 25, 2020

\section{INTRODUCTION}

Bovine viral diarrhoea virus (BVDV) is an enveloped positive-sense, single-stranded, RNA virus of approximately $12.5 \mathrm{~kb}$ in length (Richter et al. 2017). It was first described by Olafson and Rickard in 1946 and belongs to the genus pestivirus of family Flaviviridae (Becher et al. 2003; Olafson and Rickard 1947). BVDV has two biotypes (based on cellular culture analysis) cytopathic and non-cytopathic (NCP) (Bezek et al. 1994). The NCP biotype occurs most frequently and is the cause of persistent infection (Neill et al. 2008). BVDV is widely recognised as an important pathogen of dairy animals world-wide (Greiser-Wilke et al. 2003) associated with reproductive, respiratory and gastrointestinal diseases (Gunn et al. 2004). In a study, serum samples showed best sensitivity for detection of both persistent and acute transiently infected animals of BVDV (Ahmad et al., 2012). In one study, antigen captured ELISA proved suitable for detection of BVDV persistent infection (Ahmad et al. 2014). In large ruminants, BVDV is well customary pathogen triggering such type of fatalities. Involvement of infectious diseases is the main reason of reduced productivity in the bovine population of the Pakistani herds. In Pakistan, unfortunately, little attention has been paid until now to investigate the prevalence of infectious causes of low productivity and reproductive disorders in cattle and buffaloes. Though prevalence of infection of BVDV fluctuates among studies, in many populations, infection want to be rampant, triumphing maximum level of 60 $85 \%$ and $1-2 \%$ of cattle with antibody positive and persistently infected (PI) respectively. Changes in prevalence of BVDV between regions or entrance of virus in dairy herds, formerly free from BVDV, are frequently concomitant with specific epidemiological factors such as animal pasturing, trade and population density. However, on rare junctures there have been no noticeable elucidations for BVDV infection in individual herds (Houe 1999). Study of risk factors associated with BVDV is crucial as it will help to identify circumstances which conceivably are playing a part in spreading of 
BVDV infection in the dairy herds of southern Punjab, Pakistan.

\section{MATERIALS AND METHODS}

In this study three divisions of Southern Punjab province, including Bahawalpur, Multan and Dera Ghazi Khan, were selected for blood sampling. A crosssectional survey was conducted for three months to determine the prevalence of BVDV in different districts of southern Punjab. The target population was cattle and buffaloes from different herds of divisions Bahawalpur, Multan and Dera Ghazi Khan of Punjab province. Apparently healthy as well as animals showing productive and reproductive problems of different ages and sex were selected for sampling. The random sampling of cow and buffaloes was adopted in this study. The 40 different cow and buffaloes herds (with minimum 20 animals) were selected randomly in divisions Bahawalpur, Multan and Dera Ghazi Khan. From each division, 15 herds of cattle and buffaloes were selected. From each herd, 20 animals were randomly selected and were subjected to sample collection. Out of 20 animals, ten were diseased, showing productive and reproductive problems, and ten were healthy. Blood sample of both healthy and diseased cattle and buffaloes was collected from the Jugular vein. Then blood was allowed to clot to separate serum by using yellow top vacutainer (gel and clot activator). Data obtained from the owners in a face to face interview. History of animals like age, sex, breed, abortion, repeat breeding and any other reproductive disorder and other risk factors associated with BVDV were also be noted on pre-designed Performa. All the samples of cow and buffaloes were subjected to check the status of antibody against BVDV and antigen through commercially available antibody and antigen captured ELISA kit (IDEXX, USA) respectively according to the recommendation of the manufacturer (Humphry et al. 2012). To identify the persistently infected (PI) animals, the animals that have been found positive against antigen during the first round of sampling were re-sampled after 30 days and tested through antigen captured ELISA as described earlier. The animals found positive in the second round of testing were accepted as PI. To reconfirm the ELISA results, ten samples (five ELISA positive and negative each) from cattle and buffaloes were tested through more sensitive PCR test.

Extraction of RNA: Ten samples (Five ELISA positive and five negative) were processed for extraction of RNA by using commercially available QIAamp viral RNA Extraction kit (QIAGEN, Germany) according to the recommendation of the manufacturer.

Selection of Primers: The previously described primers 324/326 (Vilček et al. 1994) was used that selectively amplify 5' UTR of the BVDV genome (Table 1).
Reverse Transcriptase Polymerase Chain Reaction (one-step RT-PCR): To validate the ELISA results, onestep RT-PCR was performed by using commercially available verso 1-step RT-PCR Hot-Start Kit (ThermoFisher Scientific, Inc.). One-step RT-PCR was performed in a $25 \mu \mathrm{L}$ reaction mixture containing $5 \mu \mathrm{L}$ of RNA, $12.5 \mu \mathrm{l}$ of $2 \mathrm{X}$ HotStart master mix, 2.5ul of RT enhancer, $2 \mathrm{ul}$ of nuclease-free water and $1 \mu 1(20 \mathrm{pmol})$ of each of forward and reverse primers. Negative and positive controls were also used. For reverse transcription (cDNA synthesis), conditions were used at $50^{\circ} \mathrm{C}$ for 15 min, followed by verso inactivation at $95^{\circ} \mathrm{C}$ for $15 \mathrm{~min}$, initial denaturation at $95^{\circ} \mathrm{C}$ for $5 \mathrm{~min}$. After this, amplification step at $95^{\circ} \mathrm{C}$ for $45 \mathrm{Sec}$ were repeated 40 cycles, annealing at $57^{\circ} \mathrm{C}$ for $1 \mathrm{~min}$ and extension at $72^{\circ} \mathrm{C}$ for $1 \mathrm{~min}$ with a final step at $72^{\circ} \mathrm{C}$ for 7 minutes. The samples were kept at $4^{0} \mathrm{C}$ until being used.

Gel Electrophoresis: Amplified PCR products were visualized in the UV trans-illuminator. Agarose gel $1.5 \%(\mathrm{w} / \mathrm{v})$ was prepared containing ethidium bromide $(0.5 \mathrm{mg} / \mathrm{ml})$ in tris borate EDTA buffer. Electrophoresis was set to 100 Volt, $200 \mathrm{mAmp}$ current for 30 minutes.

Statistical Analysis: Chi-square test was performed to find out statistically significant $(\mathrm{P}<0.05)$ and nonsignificant $(\mathrm{P}>0.05)$ variables.

\section{RESULTS}

Prevalence of BVDV: In this study, a total of 719 samples from cattle $(n=651)$ and buffaloes $(n=68)$ were taken from 40 different dairy herds of southern Punjab, Pakistan. All the samples were processed for the presence of antibodies against BVDV through antibody capture ELISA. Out of all processed samples, overall, $18.77 \%$ positivity against BVDV was observed. Of 651 cattle samples, 129 samples (19.81\%) showed seroconversion against BVD virus whereas $8.82 \%(6 / 68)$ positivity was observed in buffaloes. In this study, more sero-positivity against BVDV was evidenced in cattle than in buffaloes. As far as division wise sero-prevalence of BVDV in cattle population was concerned, cattle of Bahawalpur showed more positivity $(22.51 \%, 52 / 231)$ followed by Multan $(18.53 \%, 38 / 205)$ and DG Khan $(18.13 \%$, $39 / 215$ ). On the other hand, in buffaloes, more positivity $(10.52 \%, 4 / 38)$ was noted in Multan division followed by DG Khan $(7.69 \%, 1 / 13)$ and Bahawalpur $(5.88 \%, 1 / 17)$ (Table 03). When farm wise sero-prevalence was analyzed, the highest sero-positivity $(76.47 \%)$ against BVDV was noticed in at a farm in Lodhran district of Multan division followed by Bahawalpur (70\%) and Dera Ghazi khan (70\%).

Validation of ELISA Results through PCR: All $(\mathrm{n}=135)$ antibody-positive samples were further tested for the presence of antigen using antigen captured ELISA kit, 
none of the samples was declared positive for antigen. To validate the ELISA results, a more sensitive polymerase chain reaction (PCR) test was carried out on ten per cent randomly taken samples. Out of these samples, none of the samples was found to be positive for BVDV while 288 bp positive control was shown (Fig. 01). These results showed that our samples were positive for antibody while negative for a specific antigen of this virus. As during the first round of sampling, no sample was found positive for BVDV antigen, so it was not possible to go for the second round of sampling for the detection for BVDV PI animal.

Evaluation of Risk Factors: To obtained evidence regarding the identification of risk factors associated with BVDV, a structured questionnaire, including close-ended interrogations was planned. During sampling, questionnaires were administered to either a person in charge of herd or owner if available. The facts obtained from this feedback were used to scrutinize the risk factors associated with the herd-level prevalence of BVDV. When the data were compared statistically, a significantly higher positivity $(\mathrm{P}<0.05)$ against BVDV was observed on farms where practices of keeping newly purchased animals in isolation before entry in the herd were present than at farms where no such practices were present. Whereas non-significant $(\mathrm{p}>0.05)$ difference was noted between dairy herds based on veterinary services provided regularly and as per need. Herds with biosecurity and without of biosecurity significant $(\mathrm{P}<.05)$ sero-positivity difference was observed. BVDV seropositive farms, with the history of abortion in $2^{\text {nd }}$ and $3^{\text {rd }}$ trimesters, were observed statistically by performing chi-square test, a significantly higher relation $(\mathrm{P}<.05)$ between BVDV and abortion while collection of samples when information regarding any history of diarrhea was taken, statistically analyzed diarrhea was found nonsignificant $(\mathrm{P}>.05)$. During sampling, we observed and noted the cleaning methods of animals at herd-level. Statistically $(\mathrm{P}>.05)$ no significant relation between BVDV sero-positivity and different cleaning methods of herds was observed. In this study, the samples were categorized on the basis of a number of animals at a farm. The farms having 10-25, 26-50, and >50 animals were named as small, medium and large dairy farms respectively. To know fact either BVDV positivity depends on herd size or not chi-square test was performed by using SPSS software the herd size was found significantly important $(\mathrm{P}<.05)$ showing a strong relation between sero-positivity against BVDV and herd sized (Table02) shows all studied variables statistically significant $(\mathrm{P}<.05)$ and non-significant $(\mathrm{P}>.05)$.

Table 01. Oligonucleotide primers (Vilcek et al. 1994) used to amplify BVDV Genome.

\begin{tabular}{lll}
\hline Primer & Primer Sequence & Location \\
\hline 324 & 5'-ATG CCC WTA GTA GGA CTA GCA-3' & 108-128 \\
326 & 5'-TCA ACT CCA TGT GCC ATG TAC-3' & $395-375$ \\
\hline
\end{tabular}

Table 02. Risk Factors associated with BVDV.

\begin{tabular}{|c|c|c|c|c|c|}
\hline \multirow{2}{*}{ Variable } & \multirow{2}{*}{ Category } & \multirow{2}{*}{ NO. } & \multicolumn{3}{|c|}{ BVDV ELISA Result } \\
\hline & & & +ve $(\%)$ & -ve $(\%)$ & P-value \\
\hline \multirow{3}{*}{ Herd Size } & Small & 15 & $2(13.33)$ & $13(86.66)$ & \multirow{3}{*}{0.005} \\
\hline & Medium & 16 & $5(31.25)$ & $11(68.75)$ & \\
\hline & Large & 9 & $7(77.77)$ & $2(22.22)$ & \\
\hline \multirow{2}{*}{ Veterinary Service } & Yes & 14 & $5(35.71)$ & $9(64.28)$ & \multirow{2}{*}{0.94} \\
\hline & No & 26 & $9(34.61)$ & $17(65.38)$ & \\
\hline \multirow{3}{*}{ Methods of cleaning } & Not practiced & 11 & $5(45.45)$ & $6(54.54)$ & \multirow{3}{*}{0.610} \\
\hline & Sweeping & 14 & $5(35.71)$ & $9(64.28)$ & \\
\hline & Water hosing & 15 & $4(26.66)$ & $11(73.33)$ & \\
\hline \multirow{2}{*}{ Awareness of biosecurity } & Yes & 13 & $1(7.69)$ & $12(92.30)$ & \multirow{2}{*}{0.012} \\
\hline & No & 27 & $13(48.14)$ & $14(51.85)$ & \\
\hline \multirow{2}{*}{$\begin{array}{l}\text { Isolation of newly } \\
\text { purchased animals }\end{array}$} & Yes & 13 & $1(7.69)$ & $12(92.30)$ & \multirow{2}{*}{0.012} \\
\hline & No & 27 & $13(48.14)$ & $14(51.85)$ & \\
\hline \multirow{2}{*}{ Abortion } & Yes & 8 & $7(87.5)$ & $1(12.5)$ & \multirow{2}{*}{0.001} \\
\hline & No & 32 & $7(21.87)$ & $25(78.12)$ & \\
\hline \multirow{2}{*}{ Diarrhea history } & Yes & 17 & $6(35.29)$ & $11(64.70)$ & \multirow{2}{*}{0.973} \\
\hline & No & 23 & $7(34.78)$ & $15(65.21)$ & \\
\hline
\end{tabular}


Table 03. Prevalence of BVDV in cattle and buffaloes in Bahawalpur, Multan and DG Khan Divisions.

\begin{tabular}{|c|c|c|c|c|c|}
\hline Division & Specie & $\begin{array}{c}\text { Number of } \\
\text { farms }\end{array}$ & $\begin{array}{c}\text { Number of } \\
\text { samples }\end{array}$ & $\begin{array}{l}\text { Positive } \\
\text { animals }\end{array}$ & $\begin{array}{c}\text { Percentage of } \\
\text { Positive Animals }\end{array}$ \\
\hline \multirow{2}{*}{ Bahawalpur } & Cattle & 12 & 231 & 52 & 22.51 \\
\hline & Buffalo & 1 & 17 & 1 & 5.88 \\
\hline \multirow{2}{*}{ Multan } & Cattle & 12 & 205 & 38 & 18.53 \\
\hline & Buffalo & 2 & 38 & 4 & 10.52 \\
\hline \multirow{2}{*}{ Dera Ghazi Khan } & Cattle & 12 & 215 & 39 & 18.13 \\
\hline & Buffalo & 1 & 13 & 1 & 7.69 \\
\hline \multicolumn{2}{|c|}{ Total } & 40 & 719 & 135 & 18.77 \\
\hline
\end{tabular}

Figure 01. Gel electrophoresis (PCR negative results validating antigen captured ELISA results)

\section{DISCUSSION}

Bovine-viral diarrhoea (BVD) is an infectious disease of cattle and buffaloes, caused by bovine viral diarrhoea virus (BVDV) and is distributed worldwide. Isolates of BVDV are categorised into two prime genotypes, viz. types I and II, based on serological and arrangement empathy. BVDV causes considerable economic losses to include productive and reproductive problems (Billinis et al. 2005). Regrettably in Pakistan diminutive work has been done on the prevalence of BVDV and risk factors associated with it, mostly in central and upper Punjab of Pakistan. In Pakistan, reproductive problems in animals are mostly imaginative due to brucellosis, trichomoniasis etc. while ignoring the role of BVDV because of scanty information about prevalence and risk factors associated with it. A broad and planned study was conducted to know the status of BVDV prevalence and risk factors associated with it in southern Punjab of Pakistan as southern Punjab has a high population of cattle and buffaloes. For this purpose,
40 dairy herds of three divisions of southern Punjab including Bahawalpur, Multan and Dera Ghazi Khan were selected for blood sampling. A total of 719 samples of cattle and buffaloes were collected from different herds of these three Divisions of southern Punjab, Pakistan. All collected samples were processed to check antibodies against BVDV through commercially available antibodies captured ELISA kit (IDEXX). Enzyme-linked immunosorbent assays can detect almost any immune reactive molecules and can be used as diagnostic tools to detect BVDV infected animals. In this kit $\mathrm{P} 80 / 125$ protein, which is a non-structural protein, is coated onto the 96-well microtiter plate and it is a serine like a protease related to the NS-3 protein of flaviviruses. Both cytopathogenic and non-cytopathogenic strains of BVDV contain this protein, and it is a major viral protein in virus-infected cells. This protein is found abundantly and is a well-conserved antigen, and therefore, it is used in the development of the ELISA kit for BVDV (Vanderheijden et al. 1993). In the indirect design, specific antibodies are ensnared by an immobilised viral 
antigen which is coated on the ELISA plates. The specific reaction is then detected by means of enzyme conjugated species-specific anti-antibodies. By reading the optical density (OD) of colour which developed after the addition of the substrate solution, a positive reaction was interpreted (Ahmad et al. 2013). Enzyme-linked immunosorbent assays designed to identify any immune reactive molecules and are inexpensive and fast investigative approaches. Due to many reasons, the antibody captured ELISA kit had become prominent. By using this ELISA kit, reliable results are achieved in a very short time using the serum as the sample, used for rapid screening of large-sized herds and also cell culture technique is not needed (Niskanen et al. 1991). The study revealed that there is a considerable amount of antibodies circulating in dairy herds of southern Punjab, Pakistan. A significant number of samples $(n=135)$ of cattle and buffaloes were found positive out of all processed samples $(n=719)$ showing $18.77 \%$ prevalence of BVDV. These 135 antibody-positive samples were further tested for the presence of antigen using antigen captured ELISA kit, none of the samples was declared positive for antigen. This data showed that there might be a previous exposure to BVDV that has caused the transient infection and become eliminated with time, but the circulating antibodies still existed.

Our study results regarding sero-positivity against BVDV $(18.77 \%)$ in animals of Southern Punjab are not in concordance with the high sero-prevalence reported in Bangladesh where 51.1\% sero-prevalence was observed (Uddin et al. 2017). This disagreement might be due to different management practices, poor biosecurity, little work on BVDV, presence of persistently infected animals and sharing of pasture. Our results showed less sero-positivity (18.77\%) against BVDV than those observed in Netherland, where a seroprevalence of $1.1 \%$ was testified (Veldhuis et al. 2017). This low prevalence than in Pakistan may be due to the use of good management practices, implementation of routine vaccination and BVD virus control programs by the elimination of BVDV persistently infected animals and availability of quality fodder in Netherland. Our study results (18.77\%) showed close agreement with the sero-prevalence of BVDV (17.31\%) reported in a study conducted in India (Sudharshana et al. 1999).

When comparative sero-prevalence in cattle and buffaloes was analyzed, cattle showed more seroprevalence $(19.18 \%)$ than buffaloes $(8.82 \%)$. It might be either, due to fewer buffaloes sample population or little mixing of foreign blood lines in buffaloes later are common practice in case of cattle. When farm-wise seroprevalence of BVDV in cattle was compared, high seroprevalence was found in Multan Division (76.47\%). The reason of this high sero-prevalence might be due to the high trend of purchasing of new animals without checking BVDV status, increasing the risk of infection which was noted during questionnaire. In case of buffaloes, it was also high in Multan division (10.52\%) where sharing of pasture was a common practice which is one of the risk factors associated with BVDV (Saa et al. 2012).

As for as division wise sero-prevalence of BVDV in cattle population was concerned, cattle of Bahawalpur showed more positivity $(22.51 \%, 52 / 231)$ followed by Multan $(18.53 \%, 38 / 205)$ and DG Khan $(18.13 \%, 39 / 215)$. It might be due to more number of large herd sizes in Division Bahawalpur which was found potential risk factors of BVDV in the present study.

In our hands, none of the samples was accepted positive for BVDV antigen. Our study results did not match with the findings of a researcher who had conducted a study on the prevalence of BVDV in Punjab province in which $11.41 \%$ positivity (21 out of 184 tested animals) were reported (Gohar et al. 2013). PCR test results validated ELISA findings obtained in this study. Analyses of risk factors help us to identify conditions which are responsible for the spread of infections in dairy herds. To obtained evidence regarding the identification of risk factors associated with BVDV, a structured questionnaire, including close-ended interrogations, was planned. During sampling, questionnaires were directed to either a person in charge of herd or owner if available. The facts obtained from this feedback were used to scrutinise the risk factors associated with the herd-level prevalence of BVDV. The explored variables and respective categories were as follows: herd size, (small, medium, large) veterinary assistance (yes/no), cleaning methods (sweeping/water housing/ not practiced), workers visiting other farms (yes/no), isolation of newly purchased animals (yes/no), history of abortion (yes/no), and history of diarrhea (yes/no).

When these factors were statistically analysed by performing chi-square square test, out of seven studied four variables: isolation of newly purchased animals, herd size, workers visiting other farms and abortion found to be potential risk factors associated with BVDV. When data was analysed concerning abortion as risk factors of BVDV, study naked the facts that more (77.77\%) antibodies against BVDV positive dairy herds were found where the history of abortion exist than without abortion history $(22.58 \%)$. When this data was statistically analysed it showed a strong relation between BVDV and abortion. BVD virus damages maternal placentomes and interrupt the vascular supply of nutrients and may also invade the fetuses during first and second trimester resulting in abortion. Experimental BVDV infections during this period showed the same results. Fetal infection can follow from either persistent or acute viremias. In acute infection conquest to placentomes and replication of virus occurs and it may cross to fetuses without producing any lesion. It has been shown that 
BVDV spoils maternal vascular endothelium and resulting cellular debris is absorbed by trophoblast of fetus. The virus could be transferred from dam to offspring by this mechanism, and it may also reason for placentitis, which is responsible for the high level of abortion following BVDV infection (Brownlie 1990). High seropositivity against BVDV was observed at the farms where the quarantine period was not adopted. The newly purchased animals might be persistently infected, and pregnant females may contain PI fetuses, which are the main source of spread of infection (Fernandes et al. 2016). Other reason might be newly purchased bulls for breeding purpose without checking the status of BVDV because BVDV infects the testicular tissues and can be isolated from infected bulls 'semen.

In the present study, herd size is also found potential risk factors associated with BVDV. Farms with more number of animals showed high seropositivity against BVDV than smaller sized farms. The high density of animal population act as risk factors it might be due to stress, less care and high probability of transmission of infection because of more chances of close contact of animals in large-sized herds. In our study high seropositivity $(90.90 \%)$ was observed in herds where the workers were allowed to visit other farms while low seropositivity $(50 \%)$ was observed at herds where the workers were not allowed to visit other farms. The herd size was a potentially statistically significant $(\mathrm{P}<.05)$ risk factor showing a strong relationship with the BVDV seropositivity. This high seropositivity might be due to lack of biosecurity because the virus can spread from one farm to other through the clothes and shoes of the visitor. Similar results were reported in another study done in southern Brazil, where the workers visiting other farms was found to be a potentially significant risk factor of BVDV (Almeida et al. 2013). The remaining three factors cleaning methods, veterinary assistance and diarrhoea were found to be non-significant with $\mathrm{P}$ value more than 0.05 when data was statistically analysed.

Conclusion: Based on this study results, it is concluded that dairy animals are positive for antibodies against BVDV in Southern Punjab, Pakistan. The strategy to control BVDV should be devised and implemented immediately in the field. Distinctive consideration should be given for addressing identified risk factors of BVDV, such as checking the status of BVDV before allowing entry of newly purchased animals into herds, discouraging the workers visiting other farms and encouraging the culling of animals with more abortion history.

Acknowledgements: HEC, Pakistan for funding of this research project.

\section{REFERENCES}

Ahmad, A., M. Rabbani, K. Muhammad, M. Younus, M.Z. Shabbir, A. Ghafoor, A.A. Anjum, J. Nazir, M.K. Saleemi, J. Muhammad, and A.A. Ali (2014). Comparative diagnostic applications of antigen capture ELISA and immunohistochemistry for detection of bovine viral diarrhea persistent infection. The J Anim Plant Sci. 24(4): 1019-1025.

Ahmad, A., M. Rabbani, M. Younus, M. N. Zahid, A. Javed, and A. Ghafoor (2013). Diagnostic Approaches for Detection of Bovine Viral Diarrhea Virus Persistent Infection. J. Infec. Mol Biol. 2(4): 53-60.

Ahmad, A., M. Rabbani, M.Z. Shabbir, K. Muhammad, T. Yaqub, M.K. Saleemi, R.K. Khalid, M.A.B. Shabbir, and S.Y. Alvi (2012). Comparative suitability of ear notch biopsy and serum pairs for detecting nature of bovine viral diarrhoea virus infection in dairy herds. Pakistan Vet. J. 32(3): 451-455.

Almeida, L.L., I.C.S. Miranda, H.E. Hein, W.S. Neto, E.F. Costa, F.S. Marks, C.R. Rodenbusch, C.W. Canal, and L.G.Corbellini (2013). Herd-level risk factors for bovine viral diarrhea virus infection in dairy herds from Southern Brazil. Res. Vet. Sci. 95(3): 901-907.

Becher, P., R.A. Ramirez, M. Orlich, S.C. Rosales, M. Konig, M. Schweizer, H. Stalder, H. Schirrmeier, and H.J. Thiel (2003). Genetic and antigenic characterization of novel pestivirus genotypes: implications for classification. Virol. 311(1): 96-104.

Bezek, D., Y. Grohn, and E. Dubovi (1994). Effect of acute infection with noncytopathic or cytopathic bovine viral diarrhea virus isolates on bovine platelets. Am. J. Vet. Res. 55(8): 1115-1119.

Billinis, C., L. Leontides, G. Amiridis, V. Spyrou, P. Kostoulas, and M. Sofia (2005). Prevalence of BVDV infection in Greek dairy herds. Pre. Vet. Med. 72(1): 75-79.

Brownlie J. (1990). The pathogenesis of bovine virus. Rev. sci. tech. Off. int Epiz. 9: 43-59.

Fernandes, L.G., A.H. de Campos Nogueira, E. De Stefano, E.M. Pituco, C.P. Ribeiro, C.J. Alves, T.S. Oliveira, I.J. Clementino, and S.S. de Azevedo (2016). Herd-level prevalence and risk factors for bovine viral diarrhea virus infection in cattle in the State of Paraíba, Northeastern Brazil. Trop. Anim. Health. Prod. 48(1): 157165.

Gohar, H., M. Rabbani, A. Ahmad, N. Ahmad, A.A. Sheikh, and K. Muhammad (2013). Detection of bovine viral diarrhea virus prevalent in dairy 
herds of Punjab, Pakistan. Buffalo Bull. 32: 1088-1090.

Greiser-Wilke, I., B. Grummer, and V. Moennig (2003). Bovine viral diarrhoea eradication and control programmes in Europe. Biol. 31(2): 113-118.

Gunn, G., A. Stott, and R. Humphry (2004). Modelling and costing BVD outbreaks in beef herds. Vet. J. 167(2): 143-149.

Houe, H. (1999). Epidemiological features and economical importance of bovine virus diarrhoea virus (BVDV) infections. Vet. Microbiol. 64(2): 89-107.

Humphry, R., F. Brlisauer, I. McKendrick, P. Nettleton, and G. Gunn (2012). Prevalence of antibodies to bovine viral diarrhoea virus in bulk tank milk and associated risk factors in Scottish dairy herds. Vet. Rec. 171(18): 445.

Neill, J., J. Ridpath, A. Lange, and R. Zuerner (2008). Bovine viral diarrhoea virus infection alters global transcription profiles in bovine endothelial cells. In. Animal Genomics for Anim. Health. Karger Publishers. p. 93-98.

Niskanen, R., S. Alenius, B. Larsson, and S. Jacobsson (1991). Determination of level of antibodies to bovine virus diarrhoea virus (BVDV) in bulk tank milk as a tool in the diagnosis and prophylaxis of BVDV infections in dairy herds. In. Ruminant pestivirus infections. Springer. $p$. 245-251.

Olafson, P., and C. Rickard (1947). Further observations on the virus diarrhea (new transmissible disease) of cattle. The Cornell Veterinarian. 37(2): 104.

Richter, V., K. Lebl, W. Baumgartner, W. Obritzhauser, A. Kasbohrer, and B. Pinior (2017). A systematic worldwide review of the direct monetary losses in cattle due to bovine viral diarrhoea virus infection. Vet. J. 220: 80-87.

Saa, L. R., A. Perea, I. García-Bocanegra, A.J. Arenas, D.V.J ara, R. Ramos, and A. Carbonero (2012). Sero-prevalence and risk factors associated with bovine viral diarrhea virus (BVDV) infection in non-vaccinated dairy and dual purpose cattle herds in Ecuador. Trop Anim Health Prod. 44(3): 645-649.

Sudharshana, K., K. Suresh, and M. Rajasekhar (1999). Prevalence of bovine viral diarrhoea virus antibodies in India. Rev. Sci. Tech. 18: 667-669.

Uddin, M. A., A.L. Ahasan, K. Islam, M.Z. Islam, A. Mahmood, A. Islam, K.M.F. Islam, and A. Ahad (2017). Sero-prevalence of bovine viral diarrhea virus in crossbred dairy cattle in Bangladesh. Vet.World. 10(8): 906.

Vanderheijden, N., L.De Moerlooze, D.Vandenbergh, G. Chappuis, A. Renard, and C. Lecomte (1993). Expression of the bovine viral diarrhoea virus Osloss p80 protein: its use as ELISA antigen for cattle serum antibody detection. J. Gen. Virol. 74(7): 1427-1431.

Veldhuis, A., M. Mars, C. Roos, L.V. Wuyckhuise, and G.V. Schaik (2017). Two years after the Schmallenberg virus epidemic in the Netherlands: does the virus still circulate? Transbound Emerg Dis. 64(1): 116-120.

Vilcek S., A. Herring, J. Herring, P. Nettleton, J. Lowings , and D. Paton (1994). Pestiviruses isolated from pigs, cattle and sheep can be allocated into at least three genogroups using polymerase chain reaction and restriction endonuclease analysis. Archives Virology. 136(3-4): 309-323. 